\title{
KARYAWAN CU (CREDIT UNION) PANCUR KASIH MENGHADAPI TANTANGAN REFORMASI LAYANAN MELALUI TRANSFORMASI TEKNOLOGI INFORMASI DIGITAL
}

\author{
Joko Dwitanto \\ Program Studi Magister Manajemen, Universitas Tanjungpura \\ Email: yjokodwitanto@gmail.com
}

DOI: https://doi.org/10.46880/jmika.Vol4No1.pp43-46

\begin{abstract}
ABSTRAK
Penggunaan teknologi informasi dalam berbagai bidang kehidupan saat ini tidak terhindarkan lagi, sehingga suka tidak suka, siap atau tidak siap hal ini harus dihadapi termasuk kemampuan dan kesiapan dalam menghadapai perubahan yang terjadi. Sumber daya manusia terkena imbasnya atas perubahan tersebut sehingga SDM harus mampu dan mau meng-update diri. Teknologi dan SDM harus berjalan beriringan agar tidak ada gap yang terlampau jauh sehingga penerapan teknologi pada organisasi dapat dengan mudah dilakukan karena akan berdampak pada eksistensi organisasi secara keseluruhan terutama berkaitan dengan aktivitas pelayanan yang berkaitan dengan orang banyak. Metode penelitian ini dilakukan dengan descriptive/naratif research. Sampel karyawan CUPK berjumlah 30 orang plus anggota CUPK sebanyak 10 orang. Teknik pengumpulan data berdasarkan persepsi yang disampaikan oleh responden melalui wawancara. Dari hasil wawancara menyimpulkan bahwa semua responden memiliki persepsi yang sama bahwa teknologi informasi berbasis online dapat meningkatkan kinerja karyawan dan mereka merasa siap menghadapi perubahan dan peralihan sistem kerja berbasis teknologi informasi digital dalam memberikan pelayanan terbaik pada anggota CUPK.
\end{abstract}

Kata Kunci: Credit Union, Reformasi Layanan, Tranformasi Teknologi Informasi Digital.

\section{PENDAHULUAN}

Bagi sebagian orang mungkin sudah familiar mendengar istilah $\mathrm{CU}$ dan bahkan sudah mengenalnya lebih jauh, namun sebagian lagi diyakini belum pernah mendengarnya. CU adalah singkatan Credit Union, diambil dari istilah dasar bahasa latin credere yang berarti percaya dan Union atau Unus yang berarti kumpulan. Sehingga, credit union dapat dimaknai sebagai kumpulan orang yang saling percaya dalam suatu ikatan pemersatu yang sepakat untuk menabungkan uang mereka sehingga menciptakan modal bersama untuk dipinjamkan kepada anggota dengan tujuan produktif dan kesejahteraan. (sumber: Segala Permulaan Itu Sulit/Alle Begin is Moeilijk oleh J. Budi Assa, et el., 2017). Sebenarnya CU sendiri masuk ke Indonesia pada tahun 1958 yang dibawa dan diperkenalkan oleh seorang misionaris bernama Pater Carolus Albrecht, SJ dan CU pertama kali berdiri adalah CU Kemuning di Bandung, Jawa Barat pada tahun 1970, kemudian CU mulai diperkenalkan ke beberapa daerah bekerjasama dengan lembaga sosial gereja sehingga sampailah ke Kalimantan Barat.

Awal mulanya $\mathrm{CU}$ tidak berkembang baik bahkan diantaranya gulung tikar. Atas keprihatinan ini, lembaga sosial gereja kembali memberikan kursus singkat tentang $\mathrm{CU}$, inilah titik awal yang mendorong terbentuknya CU PK (Pancur Kasih). Inisiatif berdirinya CUPK pada dasarnya adalah dorongan atas keprihatinan para tokoh-tokoh dayak terhadap keadaan orang-orang suku dayak yang notabene penghuni mayoritas Kalimantan Barat terpuruk dalam segala segi kehidupan. Orang-orang suku dayak kala itu dipandang rendah, dianggap bodoh, terpinggirkan, secara ekonomi miskin dan berpendidikan rendah. Untuk diketahui, CUPK menjual layanan, memberikan pelayanan dalam bentuk Simpan-Pinjam yang dikombinasikan dengan pemberdayaan sosial berupa pendidikan dan pelatihan, swadaya dan solideritas kepada anggota dan masyarakat secara umum. Oleh karena itu CUPK hadir sebagai wadah untuk gerakan pemberdayaan masyarakat, khususnya dalam urusan ekonomi dan sosial untuk meningkatkan taraf hidup dan status sosial masyarakat. Kehadiran CUPK ditengah masyarakat sungguh dirasakan mambawa manfaat besar untuk tercapainya cita-cita dan harapan sesuai dengan misinya.

Kini, setelah 32 tahun dalam menjalankan perannya setelah melalui berbagai lika-liku persoalan yang dihadapi, seiring perubahan zaman yang tak terhindarkan, perkembangan teknologi informasi yang 
semakin cepat dan persaingan semakin kompetitif, CUPK berbenah, menatap masa depan dan menghadapi perubahan demi perubahan, karena perubahan itu tidak ada yang abadi selain perubahan itu sendiri (Irfani Hendri, Dosen FEB Untan), sehingga CUPK mau tidak mau atau suka tidak suka harus menghadapi perubahan tersebut. Perubahan itu sendiri meliputi berbagai hal meliputi pemanfaatan teknologi informasi sebagai bagian upaya dalam memberikan layanan yang maksimal, efisien dan efektif pada anggota, sumber daya manusia yang terlibat dalam layanan tersebut dan sistem manajemen pendukung yang berbasis IT lainnya.

Tujuan artikel ini memaparkan bahwa betapa pentingnya sebuah organisasi dan SDM-nya harus siap dalam menghadapi perubahan dan perkembangan teknologi informasi yang secara langsung mempengaruhi pola dan sistem kerja yang dibangun didalamnya, terlebih jika berkaitan dengan pelayanan ke banyak orang. Obyek penelitian dalam artikel ini adalah lembaga profit non pemerintah yang bergerak dibidang pengelolaan keuangan yaitu Credit Union Pancur Kasih disingkat CUPK. CUPK saat ini memiliki kantor cabang atau disebut kantor pelayanan berjumlah 53 Kantor pelayanan yang tersebar pada 12 $\mathrm{Kab} /$ kota di provinsi Kalimantan Barat dengan jumlah anggota sebanyak 158.945 orang.

Kantor pelayanan CUPK saat ini sudah terbilang banyak sehingga untuk memudahkan koordinasi, meningkatkan efisiensi serta efektifitas antar kantor pelayanan diperlukan bantuan yaitu memanfaatkan teknologi informasi, demikian halnya dalam pelayanan terhadap anggotanya penggunaan teknologi informasi tidak bisa dihindarkan terlebih dengan kondisi geografis kalimantan barat yang luas. Sebagai gambaran saat ini CUPK: dalam memberikan kemudahan pelayanan keuangan seperti tarik dana tunai pada 3 kantor pelayanan telah menggunakan ATM (Automated Teller Machine), 53 kantor pelayanan telah terintegrasi secara online dengan single database yang terpusat (Sikopdit Online) yang mulai dikembangkan dan diterapkan sejak tahun 2014 dan sejak tahun 2016 semua transaksi keuangan anggota online dan bisa diakses real time dengan CUPK Mobile berbasis android.

\section{KAJIAN LITERATUR}

Dengan jumlah anggota dan transaksi yang sudah terbilang banyak dan dalam rangka meningkatkan akuntabilitas penyajian pelaporan keuangan yang cepat, efesien dan efektif namun berkualitas serta prima dalam memberikan pelayanan kepada anggotanya, CUPK tentu saja memerlukan alat bantu yaitu berupa pemanfaatan teknologi informasi. Namun, teknologi informasi yang secanggih apapun tidak akan bermanfaat maksimal jika tidak didukung oleh sumber daya manusia-nya, sehingga kemampuan SDM harus selalu di update, saling mendukung dan mempengaruhi. Hal ini senada dengan pendapat Gary Dessler (2010), teknologi informasi memainkan peranan yang semakin penting dalam SDM. Teknologi meningkatkan fungsi SDM dalam hal pelayanan sendiri dan pusat informasi pelanggan.

Menurut McKeown dalam Suyanto (2005), teknologi informasi merujuk pada seluruh bentuk teknologi yang digunakan untuk menciptakan, menyimpan, mengubah dan menggunakan informasi dalam segala bentuknya. Teknologi informasi adalah semua bentuk teknologi yang digunakan dan diterapkan untuk mengolah dan megirim informasi. Organisasi yang bergerak dibidang pengelolaan keuangan memandang teknologi informasi merupakan bagian yang sangat penting dan tak terpisahkan yang menentukan kemajuan ataupun kemunduran karena menyangkut berbagai macam aspek pada organisasi. Hal inipun terjadi pada CUPK, Credit Union Pancur Kasih memandang bahwa teknologi dan SDM adalah dua hal yang kini tak terpisahkan. Persaingan di bidang pelayanan keuangan semakin ketat, jika CUPK ingin maju dan mampu bersaing dengan kompetitor sejenis maupun dengan lembaga keuangan konvensional lainnya maka harus memperhatikan dua hal penting ini.

Menurut Sungmin Kang dalam Hariyani, Tuti (2014) manyatakan bahwa teknologi informasi akan membantu perusahaan untuk memperbaiki performance organisasi, hanya apabila perusahaan menggunakan teknologi informasi secara aktual dalam langkah yang efisien, sehingga penerapan teknologi baru dalam suatu organisasi akan berpengaruh pada keseluruhan organisasi, terutama pada sumber daya manusia. Masih menurut Sungmin Kang dalam Hariyani, Tuti (2014), dalam hasil penelitian menyimpulkan bahwa penggunaan teknologi informasi berpangaruh signifikan pada kinerja pegawai. Itu menunjukkan bahwa teknologi informasi dan SDM jika dikolaborasikan dengan baik akan memberikan manfaat maksimal pada organisasi, sehingga pengembangan SDM yang diintegrasikan dengan pemanfaatan teknologi informasi di zaman sekarang ini menjadi perhatian utama manajemen organisasi dalam membuat keputusan.

Hal ini juga didukung penelitian yang dilakukan oleh Yudiastra, P.P dan Darma, G.S (2015) 
yang menyimpulkan bahwa penggunaan teknologi informasi berpengaruh signifikan terhadap kinerja pegawai.

\section{METODE PENELITIAN}

Penelitian ini menggunakan metode deskriptif, peneliti akan mendeskripsikan suatu fenomena dengan berdasarkan pada pengalaman partisipan riset. Data yang terhimpun merupakan data deskriptif/data naratif. Pengumpulan data dengan cara wawancara dengan karyawan CUPK sebanyak 30 orang dan anggota yang mendapat pelayanan sebanyak 10 orang, dan merupakan persepsi beberapa kesimpulan dari penelitian terdahulu yang dibandingkan dengan obyek penelitian.

\section{PEMBAHASAN}

Jawaban hasil wawancara yang dilakukan terhadap karyawan dan anggota CUPK dapat dirangkum sebagai berikut:

1. Kasir/teller yang berkaitan langsung dengan transaksi keuangan karena penggunaan teknologi informasi sangat dominan, semua karyawan menjawab bahwa penggunaan aplikasi transaksi online berbasis teknologi infomasi terasa dapat membantu pekerjaan menjadi lebih mudah, waktu yang digunakan semakin efesien dan efektif, hal ini dapat dicontohkan pada transaksi anggota pindah tempat pelayanan yang semula memakan waktu satu hari karena harus input ulang seluruh data anggota yang pindah di tempat pelayanan yang baru, dengan penggunaan teknologi informasi berbasis online hanya satu "klik" dalam hitungan detik dapat dengan mudah pekerjaan tersebut diselesaikan. Ini berarti pekerjaan menjadi semakin efesien dan efektif dan pada akhirnya terjadi peningkatan pelayanan pada anggota, dengan peningkatan pelayanan pada anggota maka akan berdampak pada organisasi.

2. Pernyataan yang sama dari kabag simpan dan pinjam, bahwa dengan penggunaan sistem yang telah terintegrasi online memanfaatkan teknologi informasi dapat meningkatkan kinerja karyawan CUPK. Banyak pekerjaan yang dapat diselesaikan dengan mudah, cepat dan akurat sehingga efektifitas dan efesiensi biaya terwujud, hal ini dapat menekan biaya yang mungkin timbul sehingga beban organisasi menjadi lebih ringan. Contohnya adalah ketika anggota yang mengajukan pinjaman kredit, prediksi perhitungan jumlah pinjaman dengan bunga dan jangka waktu pengembalian secara otomatis dapat diketahui, sehingga dapat mempersingkat waktu dalam konsultasi kredit.

3. Dari sisi anggota menyatakan hal yang sama, seperti yang disampaikan oleh anggota bernama Aan, "pelayanan sekarang ini antriannya tidak lama". Sistem yang terintegrasi secara online dapat mempersingkat pelayanan pada anggota terutama waktu yang diperlukan anggota untuk antri ketika menyetor ataupun mengambil uang di teller. Hal ini dapat memberi rasa nyaman pada anggota, dengan rasa nyaman yang dirasakan akan berdampak pada kualitas dan loyalitas anggota dalam ber-CU dan tentu saja akan berdampak pada organisasi.

4. Penggunaan teknologi informasi berupa perangkat ATM (Automated Teller Machine) dan CUPK Mobile, terutama di tiga kantor pelayanan yang sudah dilengkapi mesin ATM benar-benar sangat memudahkan anggota dalam ambil dana tunai tanpa harus mengantri, seperti yang diungkapkan oleh anggota CUPK bernama Arif, bahwa dengan tersedianya mesin ATM dapat memudahkannya mengambil uang jika memerlukan sejumlah dana untuk berbelanja berbagai keperluan, transaksi juga dapat dilakukan dengan cepat tanpa harus mengantri dan aman. Demikian halnya penggunaan CUPK Mobile berbasis android, berbagai macam transaksi yang berkaitan dengan CUPK dapat dilakukan melalui smartphone, sehingga aktivitas transaksi dapat dilakukan dimanapun dan kapapun, tidak mengganggu aktivitas yang lain. Sehingga dunia dan CUPK dalam genggaman anggota, hal ini senada yang disampaikan oleh kabag ATM dan Mobile CUPK, pak Eko Salvinus, beliau menyatakan bahwa dengan perkembangan teknologi informasi yang semakin cepat ini khususnya CUPK yang merupakan lembaga keuangan berbasis pemberdayaan merasa terbantu dalam memberikan pelayanan yang terbaik pada anggota, terlebih CUPK merupakan lembaga keuangan yang menyasar masyarakat kelas ekonomi menengah ke bawah yang rata-rata adalah petani yang tersebar diseluruh pelosok daerah di Kalimantan Barat yang rata-rata tidak terjamah oleh lembaga keuangan konvensional lainnya (bank), dan sistem yang dikembangkan oleh CUPK merupakan jawaban atas perubahan tersebut dan merupakan tututan yang mau tidak mau, suka tidak suka harus dilakukan CUPK agar mampu 
bersaing dengan kompetitor sejenis maupun lembaga keuangan lain yang telah lebih dulu mememiliki sistem terintegrasi online skala besar. Dengan adanya CUPK mobile, anggota CUPK yang ada dipelosok desa bisa melakukan bermacam transaksi terkait keanggotaanya di CUPK yang penting ada jaringan internet, sehingga dapat memangkas biaya yang mungkin muncul jika dibandingkan harus datang jauh-jauh ke tempat pelayanannya.

\section{KESIMPULAN}

Dari hasil wawancara tersebut dengan jelas dan gamblang bahwa teknologi informasi online baik berbasis desktop maupun android sama-sama memiliki pengaruh besar dalam membantu lembaga keuangan CUPK yang berbasis pemberdayaan dalam memberikan pelayanan pada anggotanya dan dengan teknologi informasi ini pula dapat membantu lembaga secara keseluruhan agar mampu bersaing dalam dunia bisnis yang semakin ketat sehingga langkah-langkah perbaikan terus menerus dan upgrade teknologi sangat diperlukan dan harus menjadi perhatian segenap manajemen organisasi agar tidak tertinggal jauh dengan kompetitor lainnya. Ini juga harus dibarengi dengan mendorong pengembangan SDM agar mampu bersaing dan dapat mengikuti perubahan teknologi tersebut, manajemen CUPK dapat mendorong hal ini dengan memasukkan pendidikan, pelatihan dan pengembangan terkait teknologi informasi dalam program tahunan, sehingga pengetahuan, keterampilan dan informasi terus ter-upgrade. Dengan demikian, CUPK siap dalam menghadapi perubahan yang semakin cepat dan kompetisi yang semakin ketat tersebut.

\section{DAFTAR PUSTAKA}

Amin, M. H., Sjahruddin, H., Alam, S., \& Syahruni. (2016). Kapasitas Sumber Daya Manusia dan Pemanfaatan Teknologi Informasi

Konsekuensinya Pada Kinerja Karyawan. ELibrary STIE YPBUP Bongaya.

Assa, J. B., Tampajara, H., \& Endi, S. (2017). Segala Permulaan Itu Sulit (Alle Begin is Moeilijk). Yogyakarta: Penerbit Pohon Cahaya

Fitriani, D. (2018). Analisis Pengaruh Penggunaan Teknologi Informasi Terhadap Kinerja Karyawan PT. Asuransi Jiwasraya Pontianak. Cogito Smart Journal, 4(1), 160-170.
Hariyani, T. (2014). Pengaruh Penggunaan Teknologi Informasi dan Minat Pemanfaatan Teknologi Informasi Terhadap Kinerja Pegawai di BKKBN Kabupaten Madiun. ASSETS: Jurnal Akuntansi dan Pendidikan, 3(2), 75-84.

Nugroho, N. T. (2016). Pengaruh Penggunaan Teknologi Informasi Terhadap Kinerja Karyawan (Studi Kasus Karyawan STMIK Duta Bangsa). Duta.com, 11(1), 12-22.

Sari, I. A. K. T. P. dan Yadnyana, I. K. (2017). Pengaruh Kecanggihan Teknologi Informasi dan Jiwa Kewirausahaan Terhadap Kualitas Informasi Akuntansi. E-Jurnal Akuntansi Universitas Udayana, 18.2, 1635-1662.

Yudiastra, P. P. dan Darma, G. S. (2015). Pengaruh Penggunaan Teknologi Informasi, Disiplin Kerja, Insentif, Turnover Terhadap Kinerja Pegawai. Jurnal Manajemen dan Bisnis, 12(1), 151-176 